Hundreds of plates of fossils, exquisitely engraved, and maps and sections, too numerous to recount, published for the Geological Survey of Great Britain, amply testify to Mr. Lowry's rare ability as a scientific engraver. Even the familiar card-maps of each town visited year after year by the British Association were invented and produced by Mr. Lowry's skill and ingenuity.

But the days of engraving seem drawing to a close, at least so far as printing from engraved plates is concerned; but the beautiful plates prepared by Mr. Lowry cannot well be surpassed by modern lithography, save in cheapness.

Much as Mr. Lowry's work was valued by scientific men, his amiability of disposition and his modesty won for him even higher esteem among his friends. Many who knew him personally will recall his readiness on all occasions, even at great personal sacrifices, to help those who needed his assistance. His freshness of heart and kindness to young people were marked features in his character. He died on June I 5 .

H. W.

DAVID MOORE, PH.D.

THE death of the Director of the Royal Botanical Gardens at Glasnevin, near Dublin, on June 9 last, has caused a very wide-spread sorrow among the botanists and horticulturists of Europe. Although Dr. Moore had attained the age of seventy-two, yet his physical strength was but little abated, and his mental powers were as strong as they were mature. A peculiarly severe attack of acute cystitis of scarcely four days' duration deprived us of a truly excellent and amiable man.

A native of Dundee, his father, attracted by the fame of Dr. MacKay, the Director of the Botanical Gardens belonging to the University of Dublin, and well known as the author of the "Flora Hibernica," sent David Moore to Dublin to be MacKay's apprentice. The apprentice soon learnt all the master had to teach, and was not long in qualifying himself to form one of the government staff, to whom, under the superintendence of the late General Portlock, was intrusted the Ordnance Survey of Ireland. This was in I834; the Survey began in the County of Londonderry. In $\mathrm{I} \delta 37$ the first volume of its Memoirs was published, to which Moore contributed an essay on the flora of the region surveyed. Shortly after this he was elected by the then Council of the Royal Dublin Society to the charge of their Botanical Gardens at Glasnevin. These gardens are situated within a couple of miles of Dublin, and present a pleasing alternation of flat and gently rising ground, which then slopes to the borders of the little trout stream called the Tolka. They are associated with the memories of Tickell and Swift, and one walk amid old yew trees is "still pointed out as the one much frequented by the Dean when inclined to moody meditation. To enumerate the changes brought about in these Gardens during the forty years' work of Moore, would be to write his and their history. It might almost be said that he found them a mixture of pleasureground and herb-garden; he has left them with all their native loveliness shown off to its very best, and containing for their size one of the best stocked collections in Europe. As the stranger walked there he was told of the literary men who sought for rest and quietness amid their shade; to the list of these sacred memories will now be added the name of a scientific man, whose daily labour for just forty years has resulted in making them known throughout the world. Amidst the practical labours of Moore's life science was not forgotten. He ably assisted MacKay in compiling his list of Irish plants. But he also devoted a great deal of attention to compiling a history of the mosses, liverworts, and algæ of his adopted country, and as the result of his maturer labours in this direction, he published in 1872 an account of the mosses of Ireland, and four years later an account of the Irish Hepaticæ. He, conjointly with A. G. Moore, F.L.S., published an account of the geographical distribution of plants in Ireland, under the title of "Cybele Hibernica." This is scarcely the place to record the numerous "plants introduced by him to our gardens and stores, or to refer to the many interesting new hybrid forms brought into existence through his skill. For such scientific labours he was rewarded by being given the $\mathrm{Ph}$. D. of Leipzig University, and with what we know he regarded as nearly as great an honour, in having the twenty-ninth volume of the third series of the Kew Fournal of Botany dedicated to him by Sir Joseph Hooker, as " to one who, maintaining a very rich and beautiful botanic garden at a high standard of excellence, has advanced botanical science by many original observations and experiments."

Long will the memory of David Moore dwell in the minds of his many friends as that of one true and faithfui, genial and generous.

\section{THE RECENT ERUPTION OF ETNA}

PROF. SILVESTRI has, with most commendable despatch, just issued his report to the Italian Government on the recent eruption of Etna. It takes the form of a quarto pamphlet of nineteen pages, entitled Sulla doppia eruzione dell' Etna scoppiata il 26 Maggio, I879, and it is accompanied by a capital map, showing the exact extent and dimensions of the lava-streams. A reference to the map accompanying the previous article (p. 158) may help the reader to understand more clearly what follows.

At the end of our former article on the subject, we mentioned certain anomalies in the accounts of the eruption already transmitted by telegram from Rome, and at the same time asserted that we must wait for the Government Report before they could be explained. It is satisfactory to find that Prof. Silvestri has completely removed these anomalies, and has given a description of the eruption, which is so connected, reasonable, and precise, that it leaves nothing to be desired.

Silvestri considers that preparations for this eruption have been continued since 1874 , and that this is the fulfilment of the abortive attempt which was then made. On August 29, I874, a rift opened on the north-east side of the mountain, between the great crater and Mojo, and thirty-five small eruptive mouths were formed along its course, together with one larger crateriform monticule, which discharged lava. But after seven hours of activity, the dynamic forces suddenly decreased in intensity, and in two days' time nothing remained of the eruption save a few secondary manifestations. For a fortnight afterwards, however, earthquakes occurred on the north side of the mountain, and the great rift remained open. Silvestri predicted that when the next eruption came this rift would prove the point of least resistance, and that the new lava would flow from it, or from craters raised along its course. This prediction has been completely verified.

The fissure of 1874 has extended itself-on the northnorth-east towards Mojo, on the south-south-west towards Adernò. It is Io kilometres $(6.2$ miles) in length, and passes through the great crater of Etna. On May 26 , the southwestern extremity discharged lava in the direction of Adernò while simultaneously the north-eastern extremity discharged lava in the direction of Mojo, thus presenting the curious anomaly of twin eruptions on opposite sides of the mountain. The craters on the south side of the mountain were situated near the base of Monte Frumento 2,650 metres $(8,743$ feet) above the sea. There were eight eruptive mouths, from 4 to 15 metres in diameter; seven of these were open, while over the eighth was raised a monticule. The lava did not flow directly towards Adernò, I3 kilometres distant, but towards a series of monticules formed during a previous eruption, and known as Monti Grotta degli Archi. It accumulated against the 
first of these mounds, and then divided into two branches' one of which commenced to flow towards Aderno, and the other towards Biancavilla, but the supply died out at the source, and the new streams solidified at a height of 2,000 metres, having flowed for a mile and a quarter as a stream 400 metres in breadth. This stream did but little damage; it did not penetrate into the cultivated region, and but in short distance into the woody region. It came into contact, however, with a bed of snow, part of which it converted into clouds of steam, while another portion was liquefied and rushed down the sides of the mountain in a foaming torrent, carrying with it a good deal of débris.

The outflow of lava ceased on the south side of the mountain, because the lava found a vent at a lower level on the north side. As the one decreased in activity the other increased. On May 28th Silvestri visited the scene of the northern eruption. A great column of smoke appeared about $20^{\circ}$ east of north, while a shower of sand descended, producing the "sad leaden light" (la luce triste plumbea) observable during an eclipse. More than two pounds of this sand were collected in ten minutes in an inverted umbrella, and the north flanks of the mountain were soon covered with it. Silvestri ascended from Randazzo towards the new craters, and when at a height of about 2,000 metres and near Monte Nero he heard loud subterranean detonations, and perceived severe oscillations of the soil. Soon afterwards he came upon the great rift, together with several smaller ones, converging towards the principal crater. In the immediate neighbourhood of Monte Nero and Timpa Rossa three new craters were seen, from one of which dense clouds of white smoke issued, while the others emitted lava and showers of ashes and incandescent stones. Frequent flashes of lightning issued from the smoke. The stream of lava near its source emitted a very bright light which, when viewed by a direct vision spectroscope, gave the lines of hydrogen, calcium, sodium, and potassium. The lava flowed down. wards at a rapid rate: the wood of Collebasso was destroyed, and by the evening of May 29 it had flowed $6 \frac{1}{4}$ miles, destroying the bridge of Passo Pisciaro and crossing the postal road between Randazzo and Linguaglossa. On Sunday the 3 Ist the stream was rapidly approaching Mojo; the inhabitants became frightened, and brought out the figure of their patron Saint Antony, which was carried in procession to the edge of the stream, while the people fell on their knees and besought the Deity to save them from the impending danger. After the evening of June $I$ the force of the eruption began somewhat to abate, "and by the 6th inst. it was practically at an end. The lava stream ran nearly 7 miles from its source, and ultimately stopped 500 yards from the river Alcantara, and about half a mile from the village of Mojo. At its termination it is 23 feet in breadth and nearly 32 feet in height. The lava stream entered the bed of the Pisciaro torrent with a velocity of from 4 to 5 metres a minute, which was reduced to 2 metres a minute in the lower valley of less inclination. In 76 hours the lava flowed more than six miles from its source.

Indications of a disturbed volcanic condition were manifest last October, when powerful shocks of earthquake were felt in the territory of Mineo, Palagonia, Vizzini, Scordia, Militello, and Caltagirone. Mineo was the centre of disturbance, and here the shocks continued at intervals during the month of October. Loud subterranean noises were also heard at intervals. Two months later an eruption of mud and gas took place near Paternò, on the southern flanks of Etna. The mud was hot, salt, and petroleum-bearing (fango salato termale petroleifero), and its ejectment continued for several months. Towards the end of December last the whole eastern sea-board was visited by a strong shock of earthquake; and soon after. wards a great increase of smoke from the central crater of Etna showed that the dynamic activity of the mountain was unusually near the surface.
Even now we cannot regard the eruption as at an end Ten days after the cessation of the flow of lava telegrams from Rome (dated June I7) announced that the neighbourhood of Santa Venere and Guardia had been visited by repeated shocks of earthquake. A telegram on the following day announced that " an earthquake of great violence" had occurred near Aci Reale, destroying five villages. There is evidently a great deal of volcanic energy still pent up not far from the surface, and we must fear that beforelong a further outburst will relieve the imprisoned Titanic forces.

G. F. RODWELL

\section{THE ELECTRIC DISCHARGE WITH THE} CHLORIDE OF SILVER BATTERY'

II

The History OF A TUBE No. 129, Hydrogen

WTE now give an account of the very great variety of phenomena presented by the same tube charged with hydrogen, No. I29 (see Plate), under different conditions of exhaustion when used in connection with batteries of various potentials, and traversed by currents of different strengths.

This tube is 32 inches long and $I^{\circ} 6$ inch in diameter, the terminals are a straight wire and a ring, about $I$ inch in diameter, both of aluminium; it is furnished with a glass stop-cock at each end, as represented in Fig. 3. The glass stop-cocks are connected with the mercurial pumps (Alvergniat and Sprengel) and with the gas generator respectively, as shown in Fig. 5 .

Tube 129, 5th Charge of Hydrogen.-A glow at both terminals was first seen when the pressure was $17^{\circ} 2 \mathrm{~mm}$., $22,632 \mathrm{M},{ }^{2}$ with 8 ,040 cells, and great heat developed in the dark discharge near the middle of the tube. The spectroscope showed faintly the $C$ and $F$ lines.

Pressure 16.5 mm., 21,710 M, 8,040 cells. One luminosity like that on the right hand of Fig. 10, sho out from the positive and approached to within 6 inches of the negative, then receded back and disappeared.

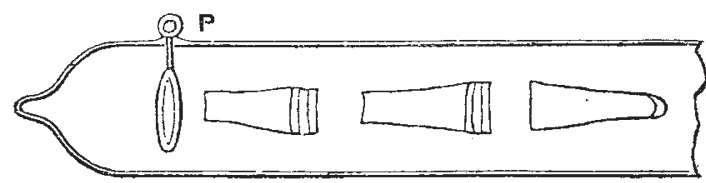

FIG. ro.

Pressure 15.8 mm., 20,789 M, 8,040 cells. 3 luminosities, very steady, which moved slowly and steadily towards the negative. The tube hottest in dark part where there was probably a non-luminous entity.

Pressure $14 \mathrm{~mm} ., \mathrm{I} 8,42 \mathrm{I} \mathrm{M}$, with 6,840 cells, the current was unsteady, but it was perfectly steady with 8,040 , and 6 arrow-headed luminosities like that on the left of Fig. II, were produced and soon disappeared.

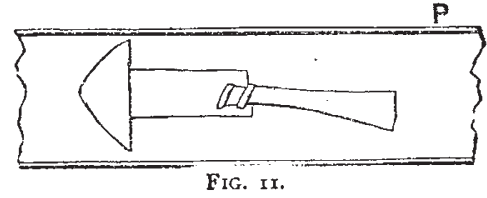

Pressure 10:3 mm., I3,552 M, with 8,040 cells. 8 luminosities something like I, Fig. I2.

Pressure $9.4 \mathrm{~mm}$, 12,368 M, with 8,040 cells. 12 luminosities like those, Fig. 7 in the Plate. The $C$ and $F$ lines seen in the glow around the negative.

Pressure $77 \mathrm{~mm}$., IO,I32 M, with 8 ,040 cells. Io luminosities like Fig. 6 in the Plate; these ran together and disappeared and reappeared in a few seconds.

I Continued from p. $7_{7}^{8}$.

$2 \mathbf{M}=$ millionths of an atmosphere 